\title{
Bovine manure and rock powder and their influences on the chemical characteristics of a Latossolo soil type (yellow oxisols) under butter kale (Brassica oleracea L. var. acephala) cultivation
}

\section{Estiércol bovino y polvo de roca y sus influencias sobre las características químicas de un tipo de suelo Latossolo (oxisoles amarillos) bajo cultivo de col rizada de mantequilla (Brassica oleracea L. var. acephala)}
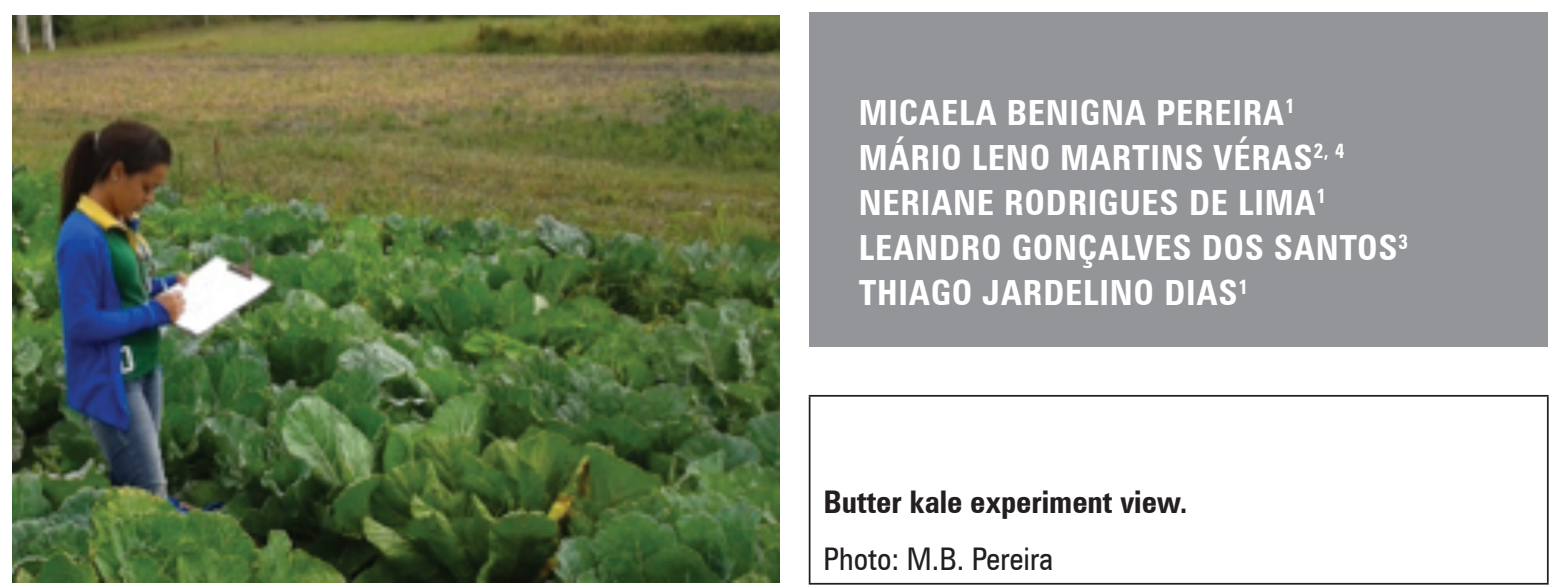

\footnotetext{
ABSTRACT

Chemical soil quality is one of the factors more quickly affected by anthropogenic degradation processes and is one of the more important components for the development of agriculture. Thus, this study aimed to evaluate the effects of different doses of cattle manure and rock powder on the chemical characteristics of soil cultivated with butter kale. The treatments were arranged in five randomized blocks in a $4 \times 4$ factorial for the different doses of bovine manure $(60,120,180$ and $240 \mathrm{~g} / \mathrm{plant})$ combined with doses of rock powder $(6$, 12,18 and $24 \mathrm{~g} /$ plant). Each block was composed of three plots, $18 \mathrm{~m}$ long and $1 \mathrm{~m}$ wide. The bed was composed of six portions, and each experimental plot consisted of 14 plants spaced at $0.40 \times 0.40 \mathrm{~m}$. At the end of the experiment, the following were analyzed: $\mathrm{pH}$, organic matter, $\mathrm{P}, \mathrm{K}, \mathrm{Na}, \mathrm{Mg}$, exchangeable acidity, cation exchange capacity (CEC), sum of base and base saturation. The doses of bovine manure and MB-4 provided an increase in $\mathrm{pH}$, organic matter, concentration of phosphorus, potassium, sodium, calcium, magnesium,

Federal University of Paraíba, Department of Plant Science and Environmental Sciences, Areia (Brazil). ORCID Pereira, M.B.: 0000-0003-0317-1481; ORCID Lima, N.R: 0000-0001-9089-7584; ORCID Dias, T.J.: 0000-0002-7843-6184

2 Federal Institute of Amapá (IFAP), Porto Grande (Brazil). ORCID Véras, M.L.M.: 0000-0001-5968-4564

3 Federal Institute Baiano (IFBaiano), Department of Plant Science, Guanambi (Brazil). ORCID Santos, L.G.: 00000001-9409-6493

4 Corresponding author. mario.veras1992@gmail.com
} 
exchangeable acidity, cation exchange capacity, sum of the base and saturation of the soil base. The doses of $240 \mathrm{~g}$ of cattle manure and $24 \mathrm{~g}$ of rock dust generated an increase in the chemical properties of the soil.

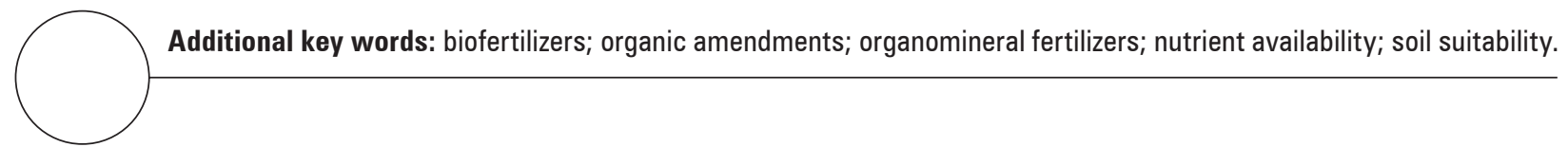

\section{RESUMEN}

La calidad química del suelo es uno de los factores más rápidamente afectados por los procesos de degradación antropogénica, y este es uno de los componentes más importantes para el desarrollo de la agricultura. Por lo tanto, este trabajo tuvo como objetivo evaluar los efectos de las diferentes dosis de estiércol de ganado y polvo de roca en las características químicas del suelo en cultivo de col rizada de mantequilla. Los tratamientos se organizaron en cinco bloques aleatorizados en un factorial de $4 \times 4$ en referencia a las diferentes dosis de estiércol bovino (60, 120,180 y $240 \mathrm{~g} /$ planta) combinado con dosis de polvo de roca (6, 12, 18 y $24 \mathrm{~g} /$ planta). Cada bloque estuvo constituido por tres parcelas de $18 \mathrm{~m}$ de largo y $1 \mathrm{~m}$ de ancho, el lecho estuvo compuesto por seis porciones y cada parcela experimental constaba de 14 plantas espaciadas en $0,40 \times 0,40 \mathrm{~m}$. Al final del experimento se analizaron: $\mathrm{pH}$, materia orgánica, $\mathrm{P}, \mathrm{K}, \mathrm{Na}, \mathrm{Mg}$, acidez intercambiable, capacidad de intercambio catiónico (CIC), suma de base y saturación por base. Las dosis de estiércol bovino y MB-4 proporcionaron un aumento en el pH, materia orgánica, concentración de fósforo, potasio, sodio, calcio, magnesio, acidez intercambiable, capacidad de intercambio catiónico, suma de la base y saturación de la base del suelo. Las dosis de $240 \mathrm{~g}$ de estiércol de ganado y $24 \mathrm{~g}$ de polvo de roca generaron un aumento en las propiedades químicas del suelo.

Palabras clave adicionales: biofertizantes; enmiendas orgánicas; organomineral fertilizers; disponibilidad de nutrientes; aptitud del suelo.

Received for publication: 24-08-2018 Accepted for publication: 29-11-2019

INTRODUCTION

Growing vegetables is done mostly conventionally. However, alternative systems such as an ecological basis using organic fertilizers such as manure are gaining prominence, especially because of both the quality of food and the environment concern (Vergel et al., 2015). This concern also extends to the forms of cultivation, driving global demand for techniques and technologies that replace the use of agriculturalindustrial inputs with high energy, economic and social costs with low-cost organic inputs. The use of organic fertilizers contributes to environmental sustainability and increases in agricultural production (Dick and Gregorich, 2004; Conway and Barbier, 2013; Souza and Resende, 2014; Li et al., 2017).

Trying to find solutions to minimize impacts on agricultural production systems which uses techniques of conventional production generating significant losses of arable land, in recent years empirical efforts of practices were carried out in ecological family production systems (Gliessman, 2000; Meirelles, 2004). The use of materials from natural sources in agricultural fertilizer has been highlighted as a way to meet and balance nutritional, chemical and biological soil needs.

The growth of organic production and ecological bases worldwide is a response to the demand from society for a sustainable environment and production practices that generate safer and healthier products for fairer social relations and trade (Lima-Filho and Quevedo-Silva, 2012; Albuquerque Júnior et al., 2013; Braga Júnior et al., 2014).

Organic fertilizers are an alternative that is easy to acquire and low cost, with several benefits, such as increased water holding capacity and infiltration, increased $\mathrm{pH}$ and ability to exchange cations (CEC), 
providing nutrients (Clemente et al., 2012; Silva et al., 2013; Dutra et al., 2015) that provide higher productivity of various vegetables, including brassica (Candian et al., 2015).

Among the materials commonly used in the composition of natural fertilizers, manure and rock powders have been widely used. Manure mainly stands out as a nitrogen source, and rock powder is an excellent alternative of calcium, magnesium, potassium and phosphorus, as well as all essential plant micronutrients (Clemente et al., 2012; Silva et al., 2013; Dutra et al., 2015; Nascimento et al., 2015, 2017).

Manure is the preferred source for supplying organic matter to soil cultivated with vegetables. Organic carbon is a power source for the microbial mass in soil; it improves soil physical, chemical and biological properties and is an important option to maintain sustainable agricultural practices (Ceretta et al., 2010; Silva et al., 2010; Yang et al., 2016).

Rock powder is a good fertilization alternative because, depending on availability, it has a low market value. It is the material that remains after breaking rocks, mainly in quarries and mining. Usually, it contains nutrients in varied amounts and quality, depending on the source of the material or rock mother.
The material can be used as a nutritional supplement, releasing nutrients over years, and, in some cases, releasing nutrients quickly (Ribeiro et al., 2010).

Therefore, the aim of this study was to evaluate the effect of different doses of manure and rock powder on the chemical characteristics of soil cultivated with butter kale.

\section{MATERIALS AND METHODS}

This experiment was conducted on Campus III of the experimental area of the Federal University of Paraí$\mathrm{ba}$, in the municipality of Bananeiras-PB (CCHSA/ UFPB), located at $6^{\circ} 45^{\prime} 4^{\prime \prime} \mathrm{S}$ and $35^{\circ} 38^{\prime} 0^{\prime \prime} \mathrm{W}$.

According to the Koppen classification, climate is considered Type As - Tropical rainy, dry summer, irregular annual rainfall distribution $(1,174.7 \mathrm{~mm})$, with a maximum annual temperature of $27^{\circ} \mathrm{C}$ and minimum of $18.8^{\circ} \mathrm{C}$, and annual average of $22^{\circ} \mathrm{C}$. The meteorological data for the experimental period are shown in Tab. 1.

The treatments were arranged in five randomized blocks in a $4 \times 4$ factorial for the doses of bovine manure $(\mathrm{BM})(60,120,180$ and $240 \mathrm{~g} /$ plant $)$ combined

Table 1. Representation of relative humidity, soil temperature, rainfall and average air temperature in the period from 0ctober 2014 to February 2015. Data from the weather station, EFSA, PB (2015).

\begin{tabular}{|c|c|c|c|c|c|}
\hline \multicolumn{6}{|c|}{ Relative humidity (\%) } \\
\hline & October & November & December & January & February \\
\hline & 87.64 & 84.39 & 84.36 & 82.32 & 82.12 \\
\hline \multicolumn{6}{|c|}{ Soil temperature $\left({ }^{\circ} \mathrm{C}\right)$} \\
\hline Layer & October & November & December & January & February \\
\hline $10 \mathrm{~cm}$ & 22.79 & 23.67 & 23.58 & 24.06 & 23.12 \\
\hline $20 \mathrm{~cm}$ & 22.94 & 24 & 23.62 & 24.17 & 25.14 \\
\hline $40 \mathrm{~cm}$ & 22.96 & 23.78 & 23.68 & 23.78 & 24.65 \\
\hline \multicolumn{6}{|c|}{ Rainfall (mm) } \\
\hline & October & November & December & January & February \\
\hline & 70.9 & 30.3 & 27.3 & 34.9 & 35.1 \\
\hline \multicolumn{6}{|c|}{ Average air temperature $\left({ }^{\circ} \mathrm{C}\right)$} \\
\hline & October & November & December & January & February \\
\hline Maximum & 22.31 & 23.01 & 23.4 & 23.87 & 22.32 \\
\hline Average & 21.52 & 22.46 & 22.58 & 22.95 & 21.56 \\
\hline Minimum & 20.81 & 21.7 & 22.01 & 22.31 & 20.85 \\
\hline
\end{tabular}


with powder rock doses (6, 12, 18 and $24 \mathrm{~g} /$ plant). The doses were selected based on the organic fertilization recommendation for leaf cabbage crops (Trani et al., 2015). Each block was composed of three plots, $18 \mathrm{~m}$ long and $1 \mathrm{~m}$ wide. The bed was composed of six portions, and each experimental plot consisted of 14 plants spaced at $0.40 \times 0.40 \mathrm{~m}$, for a total of 62,500 plants/ha, 85 portions.

The soil of the prevailing experimental area corresponded to a yellow Oxisol with a medium texture, soft curly relief, deep profile, good drainage, moderate moisture retention capacity and Sandy Clay Loam textual class.

Before conducting the experiment, 25 soil simple samples were collected in the experimental area $(0-20$ $\mathrm{cm})$. The simple samples were homogenized in containers forming five composite samples specimens; afterwards, the chemical and physical characterizations were made using the methodology suggested by Embrapa (2017). The samples had the following characteristics: sand $\left(\mathrm{g} \mathrm{kg}^{-1}\right)=740$; silte $\left(\mathrm{g} \mathrm{kg}^{-1}\right)=$ 120; clay $\left(\mathrm{g} \mathrm{kg}^{-1}\right)=140$; clay dispersed in water ( $\mathrm{g}$ $\left.\mathrm{kg}^{-1}\right)=78$; degree of flocculation $(\%)=30$; dispersion index $(\%)=56$; soil density $\left(\mathrm{kg} \mathrm{dm}^{-3}\right)=1.61$; particle density $\left(\mathrm{kg} \mathrm{dm}^{-3}\right)=2.60$; total porosity $\left(\mathrm{m}^{3} \mathrm{~m}^{-3}\right)=$ 0.49; macroporosity $\left(\mathrm{m}^{3} \mathrm{~m}^{-3}\right)=0.049$; microporosity $\left(\mathrm{m}^{3} \mathrm{~m}^{-3}\right)=0.442$; field humidity capacity to 0.01 to $1.5 \mathrm{MPa}\left(\mathrm{m}^{3} \mathrm{~m}^{-3}\right)=0.209$; wilting point tensions to 0.01 to $1.5 \mathrm{MPa}\left(\mathrm{m}^{3} \mathrm{~m}^{-3}\right)=0.134$; available water ( $\mathrm{g}$ $\left.\mathrm{kg}^{-1}\right)=0.074 ; \mathrm{pH}$ in $\mathrm{H}_{2} \mathrm{O}(1.0: 2.5)=6.50 ; \mathrm{P}(\mathrm{mg} \mathrm{dm}$ $\left.{ }^{3}\right)=69.5 ; \mathrm{K}^{+}\left(\mathrm{cmol}_{c} \mathrm{dm}^{-3}\right)=0.20 ; \mathrm{Ca}^{2+}\left(\mathrm{cmol}_{\mathrm{c}} \mathrm{dm}^{-3}\right)$ $=3.50 ; \mathrm{Mg}^{2+}\left(\mathrm{cmol}_{c} \mathrm{dm}^{-3}\right)=2.20 ; \mathrm{Na}^{+}\left(\mathrm{cmol}_{\mathrm{c}} \mathrm{dm}^{-3}\right)$ $=0.20 ; \mathrm{H}^{+}+\mathrm{Al}^{1+}\left(\mathrm{cmol}_{\mathrm{c}} \mathrm{dm}^{-3}\right)=1.50 ; \mathrm{Al}^{3+}\left(\mathrm{cmol}_{\mathrm{c}}\right.$ $\left.\mathrm{dm}^{-3}\right)=0.00$; bases sum $\left(\mathrm{cmol}_{c} \mathrm{dm}^{-3}\right)=6.1$; cation exchange capacity in $\mathrm{pH} 7\left(\mathrm{cmol}_{\mathrm{c}} \mathrm{dm}^{-3}\right)=7.6$; effective acidity (aluminum saturation) $(\%)=0.00 ; \mathrm{V}(\%)$ $=80.26$ and organic matter $\left(\mathrm{g} \mathrm{dm}^{-3}\right) 24.96$.

Butter kale seedlings of the Brassica oleracea L. var. acephala were produced in the substrate composed of vegetable soil $(60 \%)$, sand $(30 \%)$ and bovine manure $(10 \%)$ and planted in disposable cups. During the production of seedlings, a simple biofertilizer foliar application was done (Silva et al., 2012) to supply nutrients.

Conventional soil tillage preparation was used with plowing, harrowing and a subsequent lifting of the beds. Holes were made at $0.20 \mathrm{~m}$ in the transplanting seedling stage when the fertilizer was also added using bovine manure and rock powder $\left(\mathrm{MB}-4^{\circledR}\right)$ (Mineração Barreto SA - Arapiraca, Alagoas-Brasil) (Mibasa,
2007) according to the proposed treatments. The bovine manure was analyzed and had the following characteristics: $\mathrm{pH}$ in $\mathrm{H}_{2} \mathrm{O}(1.0: 2.5)=8.25 ; \mathrm{P}\left(\mathrm{mg} \mathrm{dm}^{-}\right.$ $\left.{ }^{3}\right)=5.06 ; \mathrm{K}^{+}\left(\mathrm{cmol}_{\mathrm{c}} \mathrm{dm}^{-3}\right)=0.0018 ; \mathrm{Ca}^{2+}\left(\mathrm{cmol}_{\mathrm{c}} \mathrm{dm}^{-3}\right)$ $=4.00 ; \mathrm{Mg}^{2+}\left(\mathrm{cmol}_{c} \mathrm{dm}^{-3}\right)=3.90 ; \mathrm{Na}^{+}\left(\mathrm{cmol}_{c} \mathrm{dm}^{-3}\right)=$ 1.08; $\mathrm{H}^{+}+\mathrm{Al}^{3+}\left(\mathrm{cmol}_{c} \mathrm{dm}^{-3}\right)=0.495 ; \mathrm{Al}^{3+}\left(\mathrm{cmol}_{\mathrm{c}} \mathrm{dm}^{-}\right.$ $\left.{ }^{3}\right)=0.00 ; \mathrm{Ca}^{2+}+\mathrm{Mg}^{2+}=7.90$; electrical conductivity $\left.(\mathrm{dS} \mathrm{m})^{-1}\right)=5.48$; cation exchange capacity $\left(\mathrm{cmol}_{c}\right.$ $\left.\mathrm{dm}^{-3}\right)=9.47$; base saturation $(\%)=5.10$; base sum $=$ 9.69; and organic matter $\left(\mathrm{g} \mathrm{kg}^{-1}\right)=100.82$.

The rock powder was analyzed and had the following characteristics: $\mathrm{pH}=6.80 ; \mathrm{P}\left(\mathrm{mg} \mathrm{dm}^{-3}\right)=42.82 ; \mathrm{K}^{+}$ $\left(\mathrm{cmol}_{c} \mathrm{dm}^{-3}\right)=0.12 ; \mathrm{Ca}^{2+}\left(\mathrm{cmol}_{c} \mathrm{dm}^{-3}\right)=5.65 ; \mathrm{Mg}^{2+}$ $\left(\mathrm{cmol}_{c} \mathrm{dm}^{-3}\right)=1.95 ; \mathrm{Na}^{+}\left(\mathrm{cmol}_{c} \mathrm{dm}^{-3}\right)=0.30 ; \mathrm{H}^{+}+$ $\mathrm{Al}^{3+}\left(\mathrm{cmol}_{c} \mathrm{dm}^{-3}\right)=1.70 ; \mathrm{Al}^{3+}\left(\mathrm{cmol}_{c} \mathrm{dm}^{-3}\right)=0.00$; $\mathrm{Ca}^{2+}+\mathrm{Mg}^{2+}=7.60$; cation exchange capacity $\left(\mathrm{cmol}_{c}\right.$ $\left.\mathrm{dm}^{-3}\right)=9.72$; base saturation $(\%)=97.77$; base sum $=74.56$ and organic matter $\left(\mathrm{g} \mathrm{kg}^{-1}\right)=43.85$. The rock powder came from Neoproterosóica Brasiliane s.I - Granitoids (Santo et al., 2002), composed of $55 \%$ sand, $43 \%$ silt and $2 \%$ clay.

After transplantation and fertilization, the beds were covered with straw, Brachiaria decumbens, using a 2 $\mathrm{cm}$ thick layer in order to enhance the development of biological activities, control spontaneous plants, and maintain soil moisture.

Irrigation was done with a drip system according to the water needs of the butter kale culture, adopting shifts of $9 \mathrm{~h}$ irrigation in the initial phase when the crop was established, increasing up to $1 \mathrm{~d}$ in the final stage, corresponding to the last $20 \mathrm{~d}$ of the crop cycle. Self-cleaning drippers with self-compensating emitters with a flow of $6.0 \mathrm{~L} \mathrm{~h}^{-1}$ were used, $0.40 \mathrm{~m}$ spaced between themselves and distributed along the lines. The methodology used for the irrigation calculation (Cleves et al., 2016) was based on Etc $=$ Kc $\times$ ETo (crop evapotranspiration $=$ crop coefficient $\times$ evapotranspiration of reference $\left(\mathrm{mm} \mathrm{d}^{-1}\right)$.

At the end of the experiment, $60 \mathrm{~d}$ after transplantation, the following were measured: $\mathrm{pH}$, organic matter $(\mathrm{OM})$, phosphorus content $(\mathrm{P})$, potassium $(\mathrm{K})$, sodium $(\mathrm{Na})$, calcium $(\mathrm{Ca})$, magnesium $(\mathrm{Mg})$, acid exchangeable $(\mathrm{H}$ and $\mathrm{Al})$, cation exchange capacity (CEC), base sum (BS) and base saturation (V). For the soil fertility analysis, soil samples were collected in the 0 to $20 \mathrm{~cm}$ layer. The analyses were performed at the Soil Laboratory of the Federal University of Paraiba, Campus III, Bananeiras (CP), with the method suggested by Embrapa (2017). 
The data were analyzed with analysis of variance and regression using Sisvar, and the means were compared with the Tukey test, up to $5 \%$ probability. The choice of the regression model was based on the significance of the regression coefficients using the t-test at $5 \%$ probability, the coefficient of determination $\left(R^{2}=\right.$ SOReg / SQtrat) and a biological behavior study.

\section{RESULTS AND DISCUSSION}

It was observed that the $\mathrm{pH}$, organic matter, phosphorus content, potassium, sodium, calcium, magnesium, exchangeable acidity, CEC, amount of base and base saturation presented a significant interaction between the doses of bovine manure (BM) and doses of rock powder (MB-4). The manure doses significantly influenced the variables, except $\mathrm{pH}$ and magnesium, and the rock powder doses affected the $\mathrm{pH}$, organic matter, potassium, sodium and sum of base.

There was an increase in $\mathrm{pH}$ (Fig. 1A) in the treatments with $\mathrm{BM}$ and $\mathrm{MB}-4$ interactions. The $\mathrm{pH}$ of the soil treated with the doses of $120 \mathrm{~g}$ of $\mathrm{BM}+18 \mathrm{~g}$ of MB-4 had a higher value (7.07), and the minimum value (6.71) was observed with BM $120 \mathrm{~g}+6 \mathrm{~g} \mathrm{MB}$ 4 , meaning the $\mathrm{pH}$ increased as the $\mathrm{MB}-4$ amount increased. Comparing the $\mathrm{pH}$ values before the experiment, which was 6.50, and after the experiment, the values increased with the fertilization used, but it was observed that the rising $\mathrm{pH}$ not harmed the development of butter kale.

The higher $\mathrm{pH}$ values were probably due to the buffering of bicarbonates and elemental cations introduced by the bovine manure and rock powder, such as $\mathrm{Ca}^{2+}$ and $\mathrm{Mg}^{2+}$ (Mkhabela et al., 2005). Yang et al. (2016), when working with watermelon, observed a higher $\mathrm{pH}$ in plants fertilized with $80 \mathrm{t} \mathrm{ha}^{-1}$ of bovine manure. Resende et al. (2006) also observed an increase in the $\mathrm{pH}$ of clayey soil that received doses of alkaline ultramafic rock powder.

For the phosphorus content, the highest value (169.94 $\mathrm{mg} \mathrm{dm}^{-3}$ ) was found in the soil treated with $60 \mathrm{~g}$ of $\mathrm{BM}+6 \mathrm{~g}$ of $\mathrm{MB}-4$, corresponding to the lower doses, while the smaller levels were found with the dose $120+18 \mathrm{~g} \mathrm{MB}-4$, presenting a decrease of 77.35 $\mathrm{mg} \mathrm{dm}^{-3}$ from the higher values found with fertilization (Fig. 1B).

It was also found that the phosphorus content had significant differences between the treatments, with higher levels observed in the soil at the end of the experiment (Tab. 1), when the phosphorus presented $69.5 \mathrm{mg} \mathrm{dm}^{-3}$. The increase in phosphorus in the soil may have occurred because of the increase in organic matter, as OM is an important controller of phosphorus synthesis in the soil and the availability of this element for plants depends on its fixation (Harrison, 1987; Andrade et al., 2003; Dao, 2004).

The interaction of $\mathrm{BM}$ and $\mathrm{MB}-4$ doses provided a quadratic effect on the potassium content (Fig. 1C), sodium (Fig. 1D) and calcium (Fig. 1E). For these elements, it was observed that the maximum values in the soil was obtained with the $120 \mathrm{~g}$ BM dose, leading to a dose reduction from 180 to 240 BM.

The potassium content reached maximum values in the treatment with BM $120 \mathrm{~g}+18 \mathrm{~g}$ of MB-4, 0.409 $\mathrm{mg} \mathrm{dm}^{-3}$ (Fig. 1C), twice that was measured at the beginning of the experiment $\left(0.20 \mathrm{mg} \mathrm{dm}^{-3}\right)$. Sodium presented the highest level in the treatment with BM $120 \mathrm{~g}+6 \mathrm{~g}$ of MB-4, obtaining $0.333 \mathrm{cmol}_{\mathrm{c}} \mathrm{dm}^{-3}$ (Fig. 1D). Thus, both the potassium and sodium values obtained with the soil analysis were higher after the completion of the experiment.

The lower sodium levels were observed at doses of BM $240 \mathrm{~g}$ and $6 \mathrm{~g}$ of MB-4 (Fig. 1D), indicating that doses higher than 4-MB can cause soil salinization, making it unsuitable for cultivation.

For the calcium content, it was found that the doses of $240 \mathrm{~g}$ of $\mathrm{BM}+12 \mathrm{~g}$ of $\mathrm{MB}-4$ provided an increase of $0.40 \mathrm{cmol}_{c} \mathrm{dm}^{-3}$ (Fig. 1E) when compared with the results of the soil analysis performed at the beginning of the experiment. After the experiment, the soil calcium content was $3.8 \mathrm{cmol}_{c} \mathrm{dm}^{-3}$.

The magnesium content in the soil increased as the BM doses increased, with maximum values of 3.96 $\mathrm{cmol}_{c} \mathrm{dm}^{-3}$ in the soil fertilized with $240 \mathrm{~g}$ of BM and $12 \mathrm{~g}$ of MB-4, leading to a reduction of $1.03 \mathrm{cmol}_{\mathrm{c}}$ $\mathrm{dm}^{-3}$ as a result of the application of maximum MB-4 doses. After the completion of the experiment, an increase of $1.76 \mathrm{cmol}_{c} \mathrm{dm}^{-3}$ of magnesium was observed in the soil, as compared to that observed before the experiment, with $2.20 \mathrm{cmol}_{c} \mathrm{dm}^{-3}$ (Fig. 1F).

The increases verified in the soil for the potassium, phosphorus, sodium, calcium and magnesium can be associated with the joint application of bovine manure and MB-4 since the application of bovine manure and rock powder can increase the availability of nutrients in soil because of the greater solubility of rock powder and mineralization of bovine manure 
(Camargo et al., 2012). As seen in the present study, an increase in nutrient contents in soil has been observed in different species grown under conditions of fertilization with bovine manure and/or rock dust, such as Raphanus sativus L. (Tito et al., 2019), Annona muricata L. (Malta et al., 2019), Phaselous vulgaris L. (Gotz et al., 2016); and Helianthus annuus L., Sol Noturno variety (Andrade et al., 2015).

The bovine manure and rock powder had a broadspectrum effect by acting on the chemical, physical and biological mechanisms of the soil. Because bovine manure is a source of organic matter that, when added to soil in proper amounts, promotes mineralization, that is, it is easily released to the soil solution, absorbed by the plants or leachate (Clemente et al., 2012; Silva et al., 2012, 2013).

The interaction between the doses of $\mathrm{BM}$ and $\mathrm{MB}-4$ provided an increasing effect of exchangeable soil acidity on all analyzed treatments (Fig. 2A). However, almost all observed values were lower than the

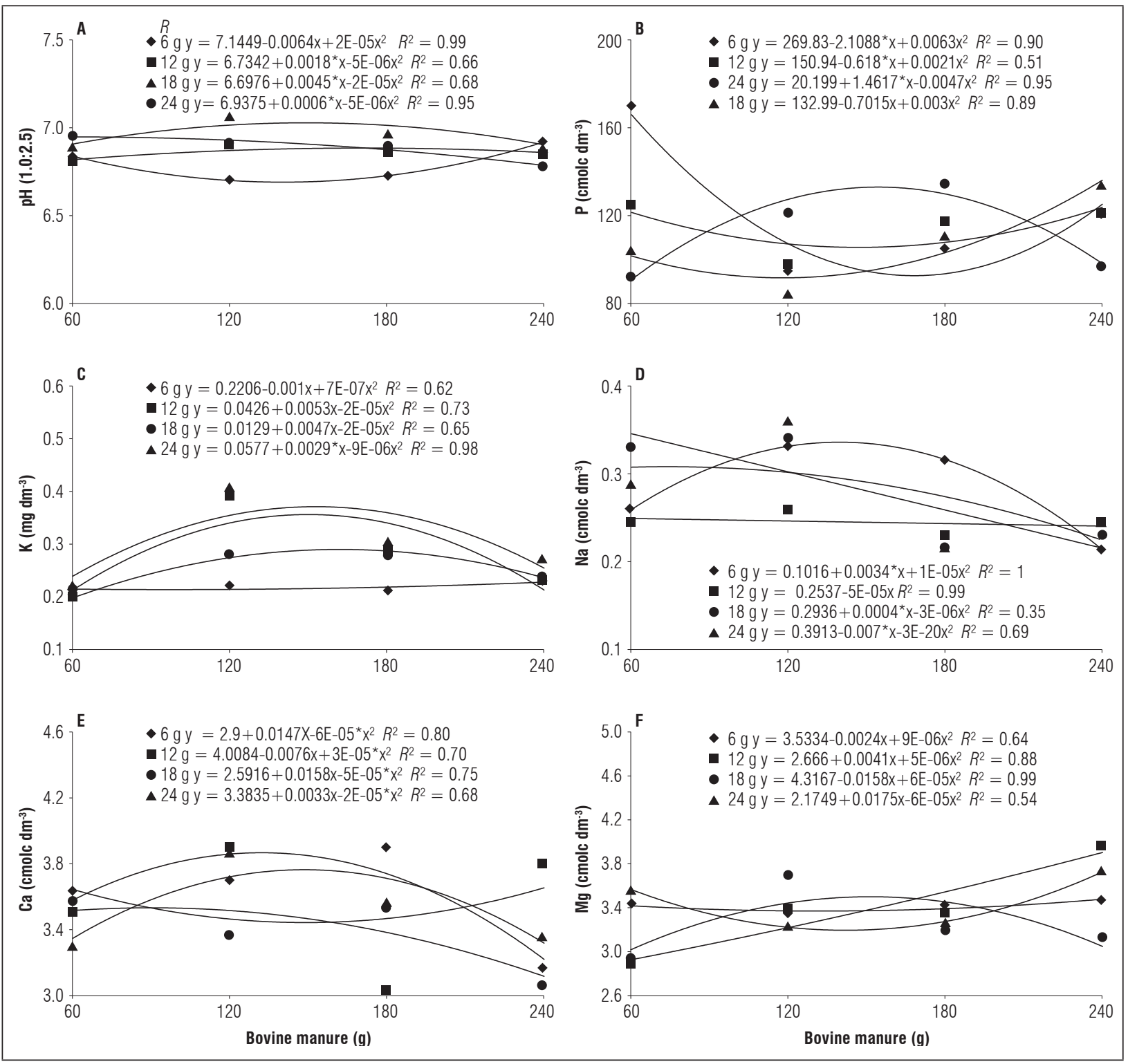

Figure 1. Effect of bovine manure doses and rock powder on the pH (A), phosphorus content (B), potassium (C), sodium (D), calcium (E) and magnesium (F) in yellow $0 x i s o l$ under butter kale cultivation. 
values in the soil analysis before the experiment, in Tab. 1, except for treatments $240 \mathrm{~g}$ of $\mathrm{BM}+12 \mathrm{~g} \mathrm{MB}$ 4, $240 \mathrm{~g}$ of $\mathrm{BM}+18 \mathrm{~g} \mathrm{MB}-4$ and $240 \mathrm{~g}$ of $\mathrm{BM}+24 \mathrm{~g}$ of MB-4, which presented slightly higher values for the initial results, respectively, 1.54 and $1.59 \mathrm{cmol}_{c}$ $\mathrm{dm}^{-3}$.

The effects of organic compounds on the exchangeable soil acidity can be associated with the complexation of Al by organic matter, which promotes the removal of that element from the soil solution and the formation of the dissolved complex by the dissolved organic carbon. The replacement of $\mathrm{Al}^{3+}$ with $\mathrm{Ca}^{2+}$ in the cationic complex immobilizes $\mathrm{Al}^{3+}$ with organic ligands, and BM reduced toxic aluminum from the ground (Hargrove and Thomas, 1981; Cancès et al., 2003; Zambrosi et al., 2007). Thus, during the decomposition of organic matter, aluminum can be complexed in the soil solution with fulvic acids (Anghinoni and Salet, 2000) or organic acids with a low molecular weight, such as citric, oxalic and tartaric acids.

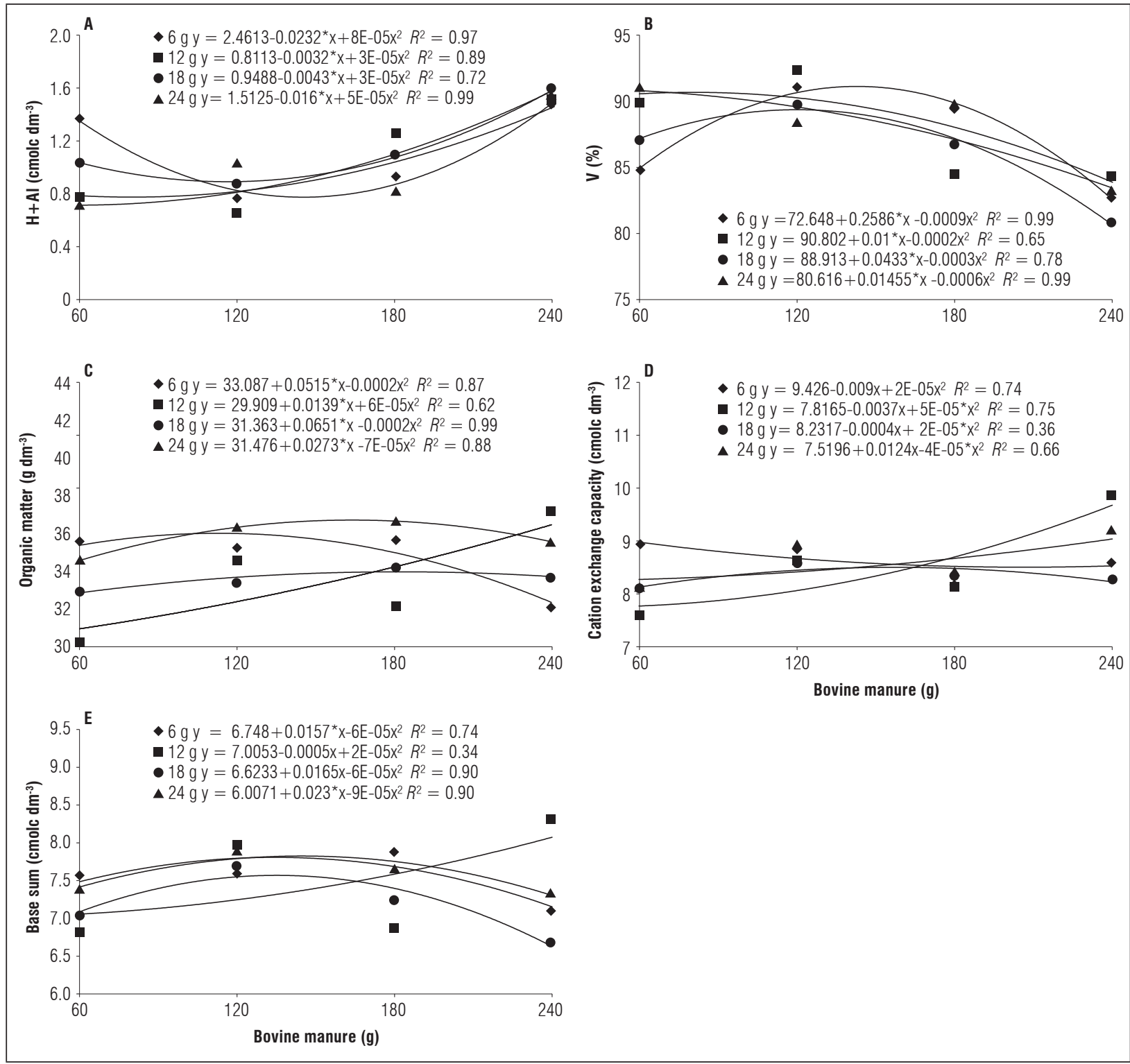

Figure 2. Effect of bovine manure and rock powder on exchangeable acidity (A), base saturation (B), organic matter (C), cation exchange capacity (D) and sum bases (E) in yellow 0xisol under butter kale cultivation. 
However, the increase of the exchangeable acidity as a result of the increase of bovine manure can also be associated with the increase of the MB-4 doses or with material mineralization processes or through removing a greater amount of nutrients by cultivated plants (Hanisch et al., 2013; Ramos et al., 2014).

For the base saturation, it was found that the interaction between the doses of $\mathrm{BM}$ and $\mathrm{MB}-4$ gave the highest interaction values, with up to $92 \%$ doses of $120 \mathrm{~g} \mathrm{BM}+12 \mathrm{~g}$ of MB-4, with a subsequent reduction of the doses of 240 to $180 \mathrm{~g}$ BM (Fig. 2B). This result shows excellent soil fertility indices, especially for the contents of the $\mathrm{Ca}, \mathrm{Mg}, \mathrm{K}$ and $\mathrm{Na}$ in the soil. May et al. (2007) emphasized that the values of the base saturation, which are for the butter kale between 70 and $80 \%$, are relevant for the productivity of this culture.

The organic matter content (Fig. 2C), cation exchange capacity (Fig. 2D) and values of the base sum (Fig. 2E) presented superior results than those observed in the initial soil characterization. And doses of $240 \mathrm{~g} \mathrm{BM}+$ $12 \mathrm{~g} \mathrm{MB}-4$ increased more than those values.

Increases in organic matter levels, cation exchange capacity and base sum values as a function of fertilization with BM and or MB-4 were also observed by Barcellos et al. (2015) when analyzing a typical dystrophic latosol Bruno, Silva et al. (2018) and evaluating a culture of Brachiaria brizantha cv. Marandú, Batista et al. (2017) in a red-yellow latosol under soybean and sorghum cultivation, and by Alovisi et al. (2017) when analyzing the availability of nutrients in soil during three incubation periods with rock dust.

The BS, CEC and V parameters were calculated with a base on $\mathrm{Ca}, \mathrm{Mg}, \mathrm{K}$, and $\mathrm{H}^{+}+\mathrm{Al}^{3}$. Therefore, as in the treatments with the greatest presence of bovine manure (120 to $240 \mathrm{~g}$ ), there was greater availability of $\mathrm{Ca}, \mathrm{Mg}, \mathrm{K}$ and a reduction of $\mathrm{H}^{+}+\mathrm{Al}^{3+}$. The $\mathrm{BS}$, $\mathrm{CEC}$ and $\mathrm{V}$ values had significant changes.

The observed results are similar to those obtained by Silva et al. (2012), where the same, testing fertilization with 6 types of rocks in a red-yellow oxisol observed that the $\mathrm{pH}$ values increased with the rock powder. For $\mathrm{Ca}, \mathrm{Mg}, \mathrm{P}$ and $\mathrm{K}$, according to these authors, there was also an increased release of these elements, which was related to the mineralogical composition of the studied rocks, where the rock powders reacted when in contact with the soil and thus were released. They also observed that the analyzed rock powders provided an increase in the $C E C$ and $V$ values of the soil.

Ribeiro et al. (2010), in a greenhouse, applied different doses of phlogopite powder, ultramafic alcaline and pyroclastic gap in a sample yellow Oxisol dystrophic and found that the rock powders released higher amounts of $\mathrm{K}$ and provided $\mathrm{P}$. These rock powders promoted further correction in the soil acidity and increased the base saturation as a result of a possible release of bases contained in the minerals of these rocks.

\section{CONCLUSION}

The doses of bovine manure and MB-4 provided an increase in $\mathrm{pH}$, organic matter, concentration of phosphorus, potassium, sodium, calcium, magnesium, exchangeable acidity, cation exchange capacity, sum of the base and saturation of the soil base.

The doses of $240 \mathrm{~g}$ of cattle manure and $24 \mathrm{~g}$ of rock dust generated an increase in the chemical properties of the soil.

Conflict of interests: The manuscript was prepared and reviewed with the participation of the authors, who declare that there exists no conflict of interest that puts at risk the validity of the presented results.

\section{BIBLIOGRAPHIC REFERENCES}

Albuquerque Júnior, E.P., J.C.L. Silva Filho, J.S. Costa, S.M. and Santos. 2013. Aspectos relativos à saúde e ao meio ambiente ligados ao consumo de alimentos orgânicos. Rev. Adm. UFSM 6, 295-312. Doi: $10.5902 / 198346598812$

Alovisi, A.M.T., M.M. Taques, A.A. Alovisi, L.K. Tokura, R.S. da Silva, and G.H.L.M. Piesanti. 2017. Alterações nos atributos químicos do solo com aplicação de pó de basalto. Acta Iguazu 6(5), 69-79.

Andrade, F.V.; E.S. Mendonça, V.V.H. Alvarez, and R.F. Novais. 2003. Adição de ácidos orgânicos e húmicos em Latossolos e adsorção de fosfato. Rev. Bras. Ciênc. Solo 27(6), 1003-1011. Doi: 10.1590/ S0100-06832003000600004

Andrade, L.O., R.G. Nobre, N. da Silva Dias, H.R. Gheyi, F.A.L. Soares, and E.C.S. Nascimento. 2015. Morfometria de plantas de girassol ornamental e atributos químicos de um solo irrigado com água residuária e adubado com esterco. Científica 43(3), 268-279. Doi: 10.15361/1984-5529.2015v43n3p268-279 
Anghinoni, I. and R. L. Salet. 2000. Reaplicação de calcário no sistema plantio direto consolidado. p. 41-59. In: Kaminski, J. (ed.). Uso de corretivos da acidez do solo no plantio direto. Sociedade Brasileira de Ciência do Solo, Pelotas, Brazil.

Barcellos, M., A.C.V. Motta, V. Pauletti, J.C.P.M. da Silva, and J.Z. Barbosa. 2015. Atributos químicos de Latossolo sob plantio direto adubado com esterco de bovinos e fertilizantes minerais. Com. Sci. 6(3), 263-273. Doi: 10.14295/cs.v6i3.527

Batista, N., V. Ragagnin, E. Hack, A. Gorgen, and E.D.S. Martins. 2017. Atributos químicos de um latossolo vermelho amarelo sob cultivo de soja e sorgo submetido ao uso de basalto moído. pp. 241-247. In: Proc. III Congresso Brasileiro de Rochagem. Embrapa Clima Temperado, Pelotas, Brazil.

Braga Junior, S.S., A.R. Veiga Neto, and N.R. Moraes. 2014. Atributos de estilo de vida do consumidor relacionados ao consumo de produtos orgânicos no varejo especializado. Rev. Bras. Mark. 13(5), 36-46. Doi: 10.5585/ remark.v13i5.2781

Camargo, C.K., J.T.V. Resende, L.K.P. Camargo, and A.S.T. Figueiredo, and D.S. Zanin. 2012. Produtividade do morangueiro em função da adubação orgânica e com pó de basalto no plantio. Semin. Ciênc. Agrár. 33(Supp. 1), 2985-2994. Doi: 10.5433/1679-0359.2012v33Sup11p2985

Cancès, B., M. Ponthieu, M. Castrec-Rouelle, E. Aubry, and M.F. Benedetti. 2003. Metal ions speciations in a soil and its solution: experimental data and model results. Geoderma 113(3-4), 641-355. Doi: 10.1016/ S0016-7061(02)00369-5

Candian, J.S., B.N.M. Martins, and A.I.I. Cardoso. 2015. Doses de composto orgânico no desenvolvimento inicial de couve-flor e nas características químicas do solo. Rev. Cultiv. Saber 8(3), 257-266.

Ceretta, C.A., F. Lorensini, G.L. Brunetto, E. Girotto, L. C. Gatiboni, C.R. Lourenzi, T.L. Tiecher, L. Conti, G. Trentin, and A. Miotto. 2010. Frações de fósforo no solo após sucessivas aplicações de dejetos de suínos em plantio direto. Pesq. Agropec. Bras. 45(6), 593-602. Doi: 10.1590/S0100-204X2010000600009

Clemente, R., D.J. Walker, T. Pardo, D. Martínez-Fernández, and M.P. Bernal. 2012. The use of a halophytic plant species and organic amendments for the remediation of a trace elements contaminated soil under semi-arid conditions. J. Hazard. Mater. 223-224, 6371. Doi: $10.1016 /$ j.jhazmat.2012.04.048

Cleves-Leguizamo, J.A., J. Toro-Calderón, and L. Martínez-Bernal. 2016. Los balances hídricos agrícolas en modelos de simulación agroclimáticos. Una revisión analítica. Rev. Colomb. Cienc. Hortic. 10(1), 149-163. Doi: 10.17584/rcch.2016v10i1.4460

Conway, G.R. and E.B. Barbier. 2013. After the green revolution: sustainable agriculture for development. Earthscan; Routledge, London. Doi: 10.4324/9781315066820
Dao, T.H. 2004. Ligands and phytase hydrolysis of organic phophorus in soils amended with dairy manure. Agron. J. 96, 1188-1195. Doi: 10.2134/agronj2004.1188

Dick, W.A. and E.G. Gregorich. 2004. Developing and maintaining soil organic matter levels. pp. 103-120. In: Schjønning, P., S. Elmholt, and B.T. Christensen (eds.). Managing soil quality: challenges in modern agriculture. CABI Publishing, Wallingford, UK. Doi: 10.1079/9780851996714.0103

Dutra, L.M.F., F.M. Barbosa, A.S. Melo, P.D. Fernandes, M.S. Vidal, J.I. Baldani, and C.H.S.G. Meneses. 2015. Inoculação de gluconacetobacter diazotrophicus e seu efeito no desenvolvimento de plantas de arroz vermelho. J. Biol. Pharm. Agric. Manage. 10(2), 86-101.

Embrapa, Empresa Brasileira de Pesquisa Agropecuária. 2017. Manual de métodos de análise de solo. $3^{\text {th }}$ ed. Brasilia.

Gliessman, S.R. 2000. Agroecologia: processos ecológicos em agricultura sustentável. Editorial da UFRGS, Porto Alegre, Brazil.

Gotz, L.F., Piovesan, F., Basso, F.J.M., Forte, and C.T. Castamann. 2016. Pó de rocha como fonte alternativa para melhoria de atributos químicos do solo e do potencial produtivo da cultura do feijão em sistemas agroecológicos. In: VI Jornada de Iniciação Cientifica e Tecnológica - Universidade Federal da Fronteira Sul, Chapeco, Brazil.

Hanisch, A.L., J.A.D. Fonseca, A.A. Balbinot Junior, and E. Spagnolo. 2013. Efeito de pó de basalto no solo e em culturas anuais durante quatro safras, em sistema de plantio direto. Rev. Bras. Agropecu. Sustent. 3(2), 100-107.

Hargrove, W.L. and G.W. Thomas. 1981. Extraction of aluminum from aluminum-organic matter complexes. Soil Sci. Soc. Am. J. 45, 151-153. Doi: 10.2136/ sssaj1981.03615995004500010032x

Harrison, A.F. 1987. Soil organic phosphorus. CAB, Wallingford, UK.

Li, H., W.-T. Feng, X.-H. He, P. Zhu, H.-J. Gao, N. Sun, and M.-G. Xu. 2017. Chemical fertilizers could be completely replaced by manure to maintain high maize yield and soil organic carbon (SOC) when SOC reaches a threshold in the Northeast China Plain. J. Integr. Agric. 16(4), 937-946. Doi: 10.1016/S2095-3119(16)61559-9

Lima-Filho, D.O. and F. Quevedo-Silva. 2012. Percepção do consumidor sobre produtos orgânicos. Rev. Bras. Mark. 11(1), 29-46. Doi: 10.5585/remark.v11i1.2297

Mantovani, J.R., M. Carrera, J.L.A. Moreira, D.J. Marques, and A.B.D. Silva. 2017. Fertility properties and leafy vegetable production in soils fertilized with cattle manure. Rev. Caatinga 30(4), 825-836. Doi. 10.1590/1983-21252017v30n402rc

Malta, A.O., W.E. Pereira, M.N.N. Torres, A.O. Malta, E.S. Silva, and S.I.A. Silva. 2019. Atributos físicos e químicos do solo cultivado com gravioleira, sob adubação 
orgânica e mineral. PesquisAgro 2(1), 11-23. Doi: 10.33912/AGRO.2596-0644.2019.v2.n1.p11-23.id212

May, A., S.W. Tivelli, P.F. Vargas, A.G. Samra, L.V. Sacconi, and M.O. Pinheiro. 2007. A cultura da couve-flor. Série Tecnologia APTA, Boletim Técnico IAC 200. Instituto Agronômico, Campinas, Brazil.

Meirelles, L. 2004. Soberania alimentar, agroecologia e mercados locais. Revista Agriculturas: experiências em agroecología 1, 11-14.

MIBASA, Mineração Barreto. MB4. In: http://mibasa.agenciafish.webfactional.com/produto/mb4/17/; consulted: April, 2018.

Mkhabela, M. and P.R. Warman. 2005. The influence of municipal solid waste compost on yield, soil phosphorus availability and uptake by two vegetable crops, grown in a Pugnash sandy loam soil in Nova Scotia. Agric. Ecosyst. Environ. 106(1), 57-67. Doi: 10.1016/j. agee.2004.07.014

Nascimento, J.A.M., J.S. Souto, L.F. Cavalcante, S.A. Medeiros, and W.E. Pereira. 2017. Produção de melancia em solo adubado com esterco bovino e potássio. Rev. Bras. Ciênc. Agr. 12(2), 122-127. Doi: 10.5039/agraria. v12i2a5427

Nascimento, J.A.M., J.S. Souto, L.F. Cavalcante, F.T. Oliveira, V. Mendonça, A.M.A. Junior, and S.A.S. Medeiros. 2015. Macronutrientes na cultura da melancia cultivada em Neossolo com esterco bovino. Rev. Bras. Ciênc. Agr. 10(2), 224-229. Doi: 10.5039/agraria.v10i2a5058

Pereira, M.B., T.J. Dias, N.R. Lima Neriane, E.D.S.J. Evandra, D.S.O. Daivyd, and M.L.M.V. Mario. 2020. Plant growth and yield of butter kale (Brassica oleracea L. var. acephala), as influenced by the combined application of bovine manure and rock powder. Acta Agron. 69(1), 38-45. Doi: 10.15446/acag.v69n1.75174

Ramos, C.G., A.G. Mello, and R.M. Kautzmann. 2014. A preliminary study of acid volcanic rocks for stonemeal application. Environ. Nanotechnol. Monit. Manage. 1-2, 30-35. Doi: 10.1016/j.enmm.2014.03.002

Resende, Á.V., C.T.T. Machado, É. de Souza Martins, M.C. de Sena, M.T. do Nascimento, L.D.C.R. Silva, and N.W. Linhares. 2006. Rochas como fontes de potássio e outros nutrientes para culturas anuais. Espaç. Geogr. 9(1), 135-161.

Ribeiro, L.S., A.R. Santos, F.S. Souza, and J.S. Souza. 2010. Rochas silicáticas portadoras de potássio como fontes do nutriente para as plantas do solo. Rev. Bras. Ciênc. Solo, 34(3), 891-897. Doi: 10.1590/ S0100-06832010000300030

Santos, E.J., S.A. Ferreira, and J.F. Silva Jr. 2002. Geologia e recursos minerais do Estado da Paraíba. Secretaria de Minas e Metalurgia, Ministério de Minas e Energia, CPRM-Serviço Geológico do Brasil, Recife, Brazil.

Silva, R.R., G.A. Freitas, J.S. Silva Carneiro, F.F. Ramalho, A.V. Melo, G. Carmo Alexandrino, and C.A.O.
Andrade. 2018. Resíduos orgânicos na recuperação de solo degradado sob pastagens de Brachiaria brizantha cv. Marandú. Global Sci. Technol. 11(2), 49-64.

Silva, J.C.P.M., A.C.V. Motta, V. Pauletti, C.M. Veloso, N. Favaretto, M. Bastos, and A.S. Oliveira, and L.F. Costa e Silva. 2010. Esterco de gado leiteiro associado à adubação mineral e sua influência na fertilidade de um Latossolo sob plantio direto. Rev. Bras. Ciência. do Solo, 34(2), 453-463. Doi: 10.1590/ S0100-06832010000200019

Silva, D.J., M.A.C. Mouco, C.A.T. Gava, V. Giongo, and J.M. Pinto. 2013. Composto orgânico em mangueiras (Mangifera Indica L.) cultivadas no semiárido do nordeste brasileiro. Rev. Bras. Frutic. 35(3), 875-882. Doi: 10.1590/S0100-29452013000300026

Silva, J.A., A.P. Oliveira, G.S. Alves, L.F. Cavalcante, A.N.P. Oliveira, and M.A.M. Araújo. 2012. Rendimento do inhame adubado com esterco bovino e biofertilizante no solo e na folha. Rev. Bras. Eng. Agríc. Ambient. 16(3), 253-257. Doi: 10.1590/S1415-43662012000300003

Souza, J.L. and P. Resende. 2014. Manual de horticultura orgânica. Vol. 1. $3^{\text {th }}$ ed. Aprenda Fácil Editora, Viçosa, Brazil.

Sun, Q., Y. Ruan, P. Chen, S. Wang, X. Liu, and B. Lian. 2019. Effects of mineral-organic fertilizer on the biomass of green Chinese cabbage and potential carbon sequestration ability in karst areas of Southwest China. Acta Geochim. 38(3), 430-439. Doi: 10.1007/ s11631-019-00320-6

Tito, G.A., L.H.G. Chaves, F.G. Souza, A.R. Cavalcante, J.D. Fernandes, and A.C.F. Vasconcelos. 2019. Efeito do vermicomposto enriquecido com pó de rochas na química do solo e cultura de rabanete. Rev. Verde Agroecologia Desenvolv. Sustent. 14(4), 506-511. Doi: $10.18378 /$ rvads.v14i4.6562

Trani, P.E., S.W. Tivelli, S.F. Blat, A. Prela-Pantano, E.P. Teixeira, H.S. Araújo, , J.C. Feltran, F.A. Passos, and M.C.S.S. Novo. 2015. Couve de folha: do plantio à pós-colheita. Boletim Técnico IAC 214. Instituto Agronômico, Campinas, Brazil.

Vergel, M., J. Martínez, and S. Zafra (2017). Cultivo de cebolla y su comportamiento en la Provincia de Ocaña. Rev. Colomb. Cienc. Hortíc. 10(2), 333-344. Doi: 10.17584/rcch.2016v10i2.5070

Yang, R., Y. Mo, C. Liu, Y. Wang, J. Ma, Y. Zhang, H. Li, and X. Zhang. 2016. The effects of cattle manure and garlic rotation on soil under continuous cropping of watermelon (Citrullus lanatus L.). Plos One 11(6), e0156515. Doi: 10.1371/journal.pone.0156515

Zambrosi, F.C.B., L.R.F. Alleoni, and E.F. Caires. 2007. Aplicação de gesso agrícola e especiação iônica da solução de Latossolo sob sistema plantio direto. Ciênc. Rural 37(1), 110-117. Doi: 10.1590/ S0103-84782007000100018 